Rozprawy Komisji Językowej ŁTN, t. LXVII, 2019

ISSN 0076-0390; e-ISSN 2450-9310

https://doi.org/10.26485/RKJ/2019/67/18

Halina Pelcowa*

(1) https://orcid.org/0000-0002-1380-4943

\title{
POGRANICZE JĘZYKOWE I KULTUROWE POLSKO-WSCHODNIOSLOWIAŃSKIE W OBLICZU TENDENCJI GLOBALIZACYJNYCH (NA MATERIALE GWAR LUBELSZCZYZNY)
}

\section{THE LINGUISTIC AND CULTURAL POLISH-EAST SLAVIC BORDERLANDS IN THE CONTEXT OF GLOBALIZATION. A STUDY BASED ON DIALECT DATA OF THE LUBLIN REGION}

This study deals with the linguistic and cultural aspects of the Polish-East Slavic borderlands as seen through the prism of local tendencies and globalization trends.

Keywords: borderland, language, culture, globalization

Słowa kluczowe: pogranicze, język, kultura, globalizacja

Pogranicze ujmujemy nie tylko jako układ terytorialnych zależności i uwarunkowań, ale także jako relacje między językiem i kulturą oraz przeszłością i współczesnością. Jest to sfera zetknięcia się i współegzystowania różnych zjawisk, nie tylko na granicy geograficznego sąsiedztwa, ale też na płaszczyźnie języka i właściwości kulturowych oraz świadomości językowo-cywilizacyjnej mieszkańców współczesnej wsi. Wpisuje się ona zarówno w tradycyjne badania dialektologiczne, jak i w dialog tradycji i współczesności. Biorąc pod uwagę przemiany językowe, kulturowe, świadomościowe, cywilizacyjno-obyczajowe, ale także uwarunkowania geograficzne, osadnicze, historyczne, możemy

* Uniwersytet Marii Curie-Skłodowskiej w Lublinie, Wydział Humanistyczny, Instytut Filologii Polskiej, Zakład Historii Języka Polskiego i Dialektologii, pl. Marii Curie-Skłodowskiej 4A, 20-031 Lublin; e-mail: halina.pelc@poczta.umcs.lublin.pl. 
w dotychczasowych analizach wskazać cztery domeny badania procesów zachodzących na pograniczach językowych i kulturowych:

1) pogranicze jako łącznik regionów i dialektów, z przenikaniem się kultur i odmian językowych sąsiadujących ze sobą narodów, w tym pogranicze geograficzne z interferencjami międzyjęzykowymi i wewnątrzjęzykowymi oraz pogranicza międzydialektalne i wewnątrzdialektalne polskie i słowiańskie [por. m.in.: MAGP; OLA; Kuraszkiewicz, 1932, s. 273-324; Mazur, 1976-1978; Łesiów, 1978, s. 279-286; Falińska, Kowalska, 1983, s. 91-100; Rieger, 1983, s. 303-312; 1997, s. 134-140; 2015, s. 107-112; Czyżewski, 1986; 1988, s. 87-93; 1994; Warchoł, 1992; Pelcowa, 1997, s. 189-211; 2001a; 2001b, s. 141-151; Kość, 1999; Rembiszewska, 2002; Pihan-Kijasowa, 2015, s. 97-104; Walczak, 2015, s. 149-156]';

2) pogranicze między gwarą a językiem ogólnopolskim, z interferencjami wewnątrzsystemowymi i międzysystemowymi, powiązanymi ze zróżnicowaniem funkcjonalnych i terytorialnych odmian języka [por. m.in.: Kucała, 1960, s. 141-156; Dunaj, 1980, s. 99-108; Kurek, 1987, s. 63-69; 1995; Dejna, 1990, s. 61-75; 1991; 1998, s. 13-22; Gala, 1994; 1997, s. 33-59; Ką́, 1994; Reichan, 1999, s. 262-278; Kąś, Kurek, 2001, s. 440-459; Sierociuk, 2006; Pelcowa, 2001a] i z nowym rozumieniem zjawisk słowotwórczych jako słowotwórstwa w gwarze, a nie słowotwórstwa gwarowego, wywodzącym się z łódzkiej szkoły dialektologicznej [m.in.: Gala, Gala-Milczarek, 2006, s. 141-149; Gala, 2008; Jaros, 2009; 2011, s. 69-80; 2016, s. 23-37; Marciniak-Firadza, 2013; Gala-Milczarek, 2016];

3) pogranicze kulturowe i językowe z gwara, ale też zwyczajami, obyczajami, wierzeniami, obrzędami, magią i symboliką ludową; w ten aspekt można włączyć często stawiane pytania: „,co badamy - nazwę czy desygnat?”, ,jaki jest wzajemny stosunek zjawisk językowych i kulturowych?” [por. m.in.: Kąś, 2001, s. 191-200; Krawczyk-Tyrpa, 2001; Pelcowa, 2001c, s. 43-59; 2009, s. 89-100; 2015a, s. 551-568; 2015b, s. 91-98; Kurek, 2003; 2010, s. 71-79; Kucharzyk, 2012, s. 67-76; Rak, 2015; Tyrpa, 2019, s. 20-32];

4) pogranicze między przeszłością a współczesnością, z tożsamością regionalną, tendencjami globalizacyjnymi i aspektem świadomościowo-mentalnościowym mieszkańców wsi [por. m.in.: Kąś, 1994; Ożóg, 2001; Kurek, 2003; 2018, s. 203-209; Cygan, 2011; Pelcowa, 2012, s. 257-264; 2017, s. 20-29; Czyżewski,

${ }^{1}$ Lista prac $\mathrm{z}$ tego zakresu jest obszerna i nie ma możliwości przywołania jej w całości w krótkim artykule, w związku z tym ze względu na ograniczenia wydawnicze podajemy tylko przykładowe opracowania, kładąc szczególny nacisk na pogranicze polsko-wschodniosłowiańskie, a zwłaszcza polsko-ukraińskie. 
2015, s. 55-66; Kucharzyk, 2016, s. 241-253] - do tego aspektu odniesiemy się w dalszych rozważaniach, biorąc za podstawę wypowiedzi gwarowe mieszkańców Lubelszczyzny².

Mamy zatem sytuację, że pogranicze językowe miesza się z pograniczem kulturowym, ale też geograficznym, nie tylko jako wąski obszar stykania się języków czy kultur, ale jako szeroki pas wzajemnych uwarunkowań współczesnych i historycznych. Nie jest też pojmowane w sensie dosłownym - jako granica, ale jako strefa zetknięcia się i współegzystowania różnych zjawisk językowych i kulturowych oraz świadomości językowo-cywilizacyjnej mieszkańców. A zatem pogranicze:

[...] choć jest [...] w oczywisty sposób kształtowane i wyznaczane przez granice państwowe $i$ administracyjne, a więc czynnik polityczny - owe wymiary: społeczny i językowy, kulturowy, mentalny, psychologiczny, niepokrywające się ze zmiennymi granicami administracyjnymi, są szczególnie doniosłe [Bartmiński, 2006, s. 14-15].

Tak ujmowane pogranicze wpisuje się w globalizację i tożsamość lokalną z pojęciem małej ojczyzny oraz kultywowaniem tradycji regionu, a zatem w dwie przeciwstawne, a jednak wzajemnie dopełniające się przestrzenie. $\mathrm{W}$ obu:

[...] zaznacza się dwoistość postrzegania i konceptualizacji świata, wyraźnie uwidaczniająca się we współczesnej wsi, której język i kultura sytuują się między ciągłością i trwaniem a zmianami wyznaczającymi nowe trendy kulturowe, obyczajowe i świadomościowe [Pelcowa, 2016, s. 89].

Globalizacja, przez zaoferowanie nowej jakości życia, wprowadza zmianę w procesie postrzegania świata - z nowymi narzędziami i formami przekazu informacji, a także innym sposobem funkcjonowania mieszkańców wsi. Prowadzi to do uniwersalizacji wartości i norm kulturowych, a tym samym do zacierania granic między przeszłością a współczesnością, z komercyjnym wykorzystaniem dziedzictwa przeszłości oraz upowszechnieniem w skali globalnej określonych wzorców kulturowych, wywodzących się z kultury obcej danej społeczności. $\mathrm{Z}$ drugiej strony globalizacja otwiera nowe perspektywy rozwoju i upowszechnienia tego, co ważne lokalnie, co buduje nową, lepszą jakość codziennej egzystencji. Dzięki łatwej i powszechnej formie komunikowania się, ale też przez stwarzanie zagrożenia uniwersalizacją prowadzi do ,wyrazistszego dostrzeżenia tego, co tradycyjne i ograniczone terytorialnie, co wyraźnie wyróżnia i nadaje

2 Bazujemy na obserwacjach zachowań językowych mieszkańców wsi na Lubelszczyźnie (obszarze Polski środkowo-wschodniej ograniczonym terytorialnie do obecnego województwa lubelskiego). Są to wypowiedzi stu osób w wieku 70-90 lat, zebrane w latach 2000-2018 w pięćdziesięciu miejscowościach. Ze względu na ograniczenia objętościowe w dalszej części artykułu przywołujemy tylko wybrane fragmenty wywiadów terenowych, reprezentatywne dla całości. 
indywidualny rys" [Pelcowa, 2016, s. 91], a tym samym pozwala odkryć na nowo małą ojczyznę, z pamięcią wpisaną $\mathrm{w}$ dziedzictwo przodków, z językiem i kulturą miejsca urodzenia, pochodzenia i zamieszkiwania. Mała ojczyzna jawi się zatem jako realna przestrzeń geograficzna i społeczno-kulturowo, ale też miejsce symboliczne czy magiczne, z wplecionym patriotyzmem lokalnym. Jednak włączenie w globalny świat powoduje często rozluźnienie więzów społecznych, zanik solidaryzmu międzyludzkiego oraz działania nastawione na gwarę i kulturę ludową jako element marketingowy, często nawet w takiej wersji, w jakiej już dawno nie istnieje. Służy to komercji - z produkcją gwary i ludowości na sprzedaż, ale też ma dobre strony - pokazuje chęć zaznaczenia własnej tożsamości, odrębności i swojego miejsca w globalnej przestrzeni, z pozytywnym i emocjonalnym wartościowaniem tego, co nasze, a tym samym wymagające pokazania w możliwie najlepszej odsłonie. A zatem globalizacja pozornie zagrażająca tradycyjnemu systemowi wartości i tożsamości lokalnej z małą ojczyzną, może też stanowić dla niej wzmocnienie i dawać większe możliwości rozwoju. Ten sposób konceptualizacji otaczającego świata przekłada się na wszystkie aspekty życia - od języka po kulturowe i obyczajowe formy postępowania i zachowania, ujawniające się w postrzeganiu i przeciwstawianiu tego, co moje - cudzemu, bliskie - dalekiemu, swojskie - obcemu, na przykład:

U nas je najlepi, najładni, czyściuteńko, domy zadbane, takich ogródków to w żadny wsi ni zubaczy, a kwiaty jeszcze takie jak moja babcia sadziła, i musi nigdzie tak nie pachno jak tu (Janiszkowice, powiat opolski);

Kutia to tradycyjna potrawa na Wigilie, taka nasza, tutejsza, i tak w roku to sie ji nie gutuje, tylko na Wigilie, bo to ważna potrawa, taki symbol świąt jest, narodzenia Jezusa. No bo to skucia sie tam tyn pęcak, pszenice niby, mak obowiązkowo, miód. Ale to w innych strunach ty kuti nie gutujo, ale tu tylko u nas, bo tu ta tradycja sie zachowuje (Borowiec, powiat bikgorajski);

To wynika z naszy tradycji, jeszcze z dziada pradziada tak nazywali, i matka moje i babcia tak nazywali, to i my tak mówim, po co nam inaczy to nazywać jak to dereza (roślina leśna, widłak pospolity) i tyle, puwiesić jo to zło z chałupy ucieknie, ale i specjalnie podkidali gałązke derezy, żeby ludzie sie kłócili, no to już taka nasza tradycja, tylko tu u nas to jest, nigdzie więcy (Dorohusk, powiat chełmski).

To, co nowe, chociaż obce, jest dobre cywilizacyjnie, ale jednocześnie złe kulturowo i społecznie, na przykład:

Teraz smutynia, ludzie w domach siedzo i nicht nikogo nie obchodzi, każden sobie i tylko dla siebie. Kiedyś to zwyczaje różne, kolędniki chodziły, połaźniki, a wesela były z oczepinami, i korowaj był, i chmiela śpiwali, a tera kręco sie w kółko i tyle (Zielone, powiat zamojski);

Te ćmy to takie dusze, co ni mogo trafić do nieba, błąkajo sie, przylatujo do światła lampy, bo myślo, że to już niebo, bo one takie bidne, brzydkie, ni jak te motyle. To takie powieści 
jeszcze z dawien dawna, ale te ćmy to jich i tera pełno. Dawno to tak to sie thumaczyło, i wszystko było wiadome, a tera spytać kogo, nie wi, bo ludzie mni wiedzo, choć majo te komputery (Stefankowice, powiat hrubieszowski).

Globalizacja w zakresie mentalnościowym, świadomościowym jest częściowa, wybiórcza. Cywilizacja i jej wytwory weszły do środowiska wiejskiego, rewolucjonizując życie na tyle, że zmieniło się ono zewnętrznie, natomiast mentalnościowo pozostało takie samo. Mieszkańcy wsi starszego pokolenia nie zmienili swoich upodobań, często też mowy, dalej posługują się gwarą. Zmieniło się za to ich otoczenie, na przykład nie używają telefonu, tylko komórki, ida na impreze, organizuja pikniki, maja biznesy. Jednak, mimo wyraźnych oznak nowoczesności i doskonałej orientacji we współczesności, spotyka się jeszcze osoby, które wierzą w dawne przesądy, będące także współczesnymi przestrogami, na przykład:

Jak już matka sie cieszyli, że dobry rok bedzie, to przylazła ta wiedźma do chliwa, popatrzała, nogi obtarła, dwa razy sie ubkręciła i krowy mlika więcy dać ni chciały. Pole tyż ni obrodziło, zboża na chlib ledwo starczało. So takie baby wiedźmy, so i tera, to sie nie zmieniło i trzeba sie strzec taki czarownicy (Zamch, powiat biłgorajski);

Jak sadzili kartofle, to źle było jak wyszed też sadzić sąsiad, wtedy nas zasadzi, ni bedzie u nas kartofli, i to do dziś sie sprawdza (Rogóźno, powiat tomaszowski).

Ocena globalnego i lokalnego świata jest ambiwalentna. Tworzy się szeroki obszar pogranicza, w którym globalizacja to zarówno obcość, jak i swojskość, a mała ojczyzna kojarzona ze swojskością ma wymiar tożsamościowy, z lokalnym patriotyzmem, ale też z komercyjnym wykorzystaniem dziedzictwa i rozmyciem gwary w przestrzeni zarówno regionalnej, jak i ogólnopolskiej, z niejasną granicą między tym, co dawne i współczesne, między niekonsekwentnym i wybiórczym używaniem gwary i języka ogólnopolskiego oraz pojmowaniem tradycji (zarówno tego, czym jest, jak i, czym być nie powinna).

Utrwalony w świadomości badanych osób obraz tradycji ma kilka istotnych aspektów, z których najpełniej zaznaczają się: kulturowy, aksjologiczny i świadomościowy, a nieco słabiej: bytowy, społeczny i psychologiczny. Ludzie niejednokrotnie boją się mówić o tradycji i różnych jej przejawach, żeby nie być posądzonym o zacofanie, niedouczenie, hołdowanie zabobonom, albo nadużywają tego pojęcia - i wtedy tradycją jest wszystko, co dawne. Jest to przeszłość, wiara i powinność, ale także ciągłość i czas oraz to, co wpływa na współczesne zmiany, wpisujące się w wartości odziedziczone po przodkach. Jest to - dla ludowego oglądu świata - między innymi praca na roli, zespół działań obrzędowych i obyczajowych, wyznaczających małą ojczyznę z jej uwarunkowaniami społecz- 
nymi i kulturowymi oraz bogactwem i wielością nazw czynności i przedmiotów codziennego użytku.

Mimo ścierania się różnych prądów kulturowych i tego, jak głęboko sięgają współczesne przemiany cywilizacyjne i świadomościowe, tradycja jest wyznacznikiem działań mieszkańców wsi, wpływającym na sposób postępowania i zachowania. Jest wartością autoteliczną, czymś trwałym, niezmiennym, przekazywanym z pokolenia na pokolenie (por. m.in.: Pelcowa, 2009, s. 89-100), na przykład:

Mnie to przekazali, to ja przekazuje swoim dzieciom. Tradycja taka jest (Miętkie, powiat hrubieszowski);

To już z dziada pradziada przekazywane to było, ji łopłatek sie nosiło krowom w Scepana, no bo to taka tradycja, no to najlepse wytlumacenie. $Z$ dawna dawien taka była tradycja, tak łobchodziły nase dziadki, pradziadki, ji łojce nase, ji my tak łobchodzimy święta. No co tu wiący, przecież to już tyle lat, a nic innego ludzie nie wymyśliły (Borowa, powiat puławski); Andrzejki stąd, bo to na Andrzeja to święto, taka tradycja, musowo było. Schodziły sie dziewuchy w wieczór ji piekły kukiełki. [...]. Ji psisko przyszed ji zeżarł wszystkie te kukiełki po kulei. Jak sie łojad, był grubszy jak dłuższy. No to trza było go przez kalisony przeciagnuć. To była taka tradycja, on musiał przejść, żeby wszystkie panny wyszły po kulei za mąż (Nowa Wieś, powiat biłgorajski);

Gotowali boszcz, kapuste, kulasze, tak to nazywali, i dawno to jeszcze wszystkie jedli z jedny miski, to już taka była tradycja (Stryjów, powiat krasnostawski);

Choinka to stąd, że w raju było drzewo dobrego i złego. Ludzie zgrzeszyli przecież przez to jabko z tego drzewa, ale została choinka, żeby ubierać, bo Chrystus przyszeł odkupić świat $\mathrm{i}$ te ludzkie winy. A te jabka na choince to to stąd, że to drzewo dobrego i złego jabka miało, a te łancuchy to znowóż babcia mi opowiadali, że to łancuchy oznaczajo grzechy pierszych ludzi, co to potem Chrystus Odkupiciel te grzechy zgładził. To taka legenda i taka nasza tradycja z to choinko (Dys, powiat lubelski);

Gutujo dwanaście potraw i każdy trza skusztować, bo to na dwanaście miesięcy, żeby sie szcześciło, taka to była tradycja (Siedliska, powiat krasnostawski);

Wesela zawsze kiedyś były tradycyjne. Przyjechało wesele to trzy razy orkiestra grała, nim panna młoda wyszła z mieszkania. Trzy razy orkiestra musiała zagrać. Tak ji ten pan młody stał przed tym mieszkaniem, aż panna młoda wyszła. Jak wyszła, przywitała sie z nim, wprowadzili jich do mieszkania, no ji poszła łubrać sie w welon, sukienke, do ślubu już. Orkiestra grała, przeprosiny były, stawała ojciec, matka ji krzesny łojce, ji łona trzy razy musiała całować rodziców w twarz ji w ręke. Pożegnać sie, że już za to wychowanie matki, ojca. Tak. Ji pojechała wtedy do ślubu. A jak przyjechała ze ślubu to wychodzono do niej z chlebem ji z solo, tak, ji tak mówiono, daje wam ten chleb we dwoje, żebyście sie dorobili łoboje. Tak, ji wtedy wchodzo do mieszkania już, sadzajo jich za stół, no ji wtedy radość już śpiewania. I ta tradycja nasza jest do dziś (Turobin, powiat biłgorajski);

Ten krzyż to nasza tradycja, taki symbol. To postawili jeszcze nasze przodki ten krzyż przeciw pomorowi (Wierzchowiska, powiat janowski). 
Wypowiedzi gwarowe, stanowiące podstawę materiałową artykułu, są z jednej strony przykładem wyraźnego waloryzowania przeszłości, a z drugiej jej porównania ze współczesnością na zasadzie równorzędności lub przeciwstawienia, czemu towarzyszą temporalne wykładniki czasu, następstwo wydarzeń i kwalifikatory wartościujące, pozwalające dostrzec zachodzące zmiany oraz wydobyć różnice kulturowe między wsią dawną a współczesną, na przykład:

Nachodziły Zielone Świątki to sie jeździło do lasu, nacieło sie brzozy ji koło każdego mieszkania przed drzwiami robiło sie takie ganki z ty brzozy. A dziwczyny to latały na łąki ji narywały lepiechu, ji to sie kładło po mieszkaniach po podłodze, [...], a wszystko zgodnie z tradycjo. Tera na to ni zważajo (Czernięcin Główny, powiat biłgorajski);

Kiedyś to taka była tradycja, że nie przeszed na polu koło ciebie jak nie powiedział Boże dopomóż, a tera inaczy, tera dzień dobry mówio i tyle, a to nie po naszemu i nie po bożemu. Nie ma już żadny tradycji, musi ta Unja tak każe robić i robio (Susiec, powiat tomaszowski);

Dziś tradycji nie uważajo, nikt ni ma czasu, nic sie ludziom nie chce, jeszcze na pole nie wyjdzie a już każdyn zmęczony, wszystko maszyny robio (Dobryń, powiat bialski).

Granice między przeszłością a współczesnością są trudne do wyznaczenia, bo mamy różne postawy przekładające się na zachowanie i świadomość językową:

1) niemal wszystko, co łączy się z dotychczasową przestrzenią językową i kulturową wsi, należy do przeszłości,

2) teraźniejszość miesza się z przeszłością,

3) teraźniejszość jest sytuowana w przeszłości,

4) oba światy stykają się i funkcjonują wspólnie.

Jest to efekt globalizacji, która z jednej strony prowadzi do wyeksponowania tradycji i bogactwa językowo-kulturowego małej ojczyzny, a z drugiej ,powoduje oczyszczenie z tradycji” i umieszcza w przeszłości nawet te elementy, które są obecne współcześnie i mają wymiar ponadczasowy, uniwersalny (np. odniesienia religijne). Ponadto często wartościowane pozytywnie i przenoszone deklaratywnie elementy z przeszłości nie tylko nie są realizowane obecnie, ale też nie należały do systemu wartości przodków.

\section{ROZWIĄZANIA SKRÓTÓW}

MAGP - Nitsch Kazimierz (t. I-II), Karaś Mieczysław (t. III-XIII), red., 1957-1970, Mały atlas gwar polskich, opr. zespół Pracowni Atlasu i Słownika gwar polskich, Zakład Narodowy im. Ossolińskich, Wrocław.

OLA - Obszczesławjanśkij lingwisticzeskij attas, 1988 i nast., Moskwa. 


\section{BIBLIOGRAFIA}

BARTMIŃSKI Jerzy, 2006, Ludowe parateksty w kulturze pogranicza polsko-ukraińskiego, w: H. Pelcowa, red., Spotkania polsko-ukraińskie. Język - Kultura - Literatura, Wydawnictwo Państwowej Wyższej Szkoły Zawodowej, Chełm, s. 13-39.

Cygan Stanisław, 2011, Przejawy świadomości językowej mieszkańców wsi końca XX wieku na przykładzie Lasocina na Kielecczyźnie, Wydawnictwo Uniwersytetu Humanistyczno-Przyrodniczego Jana Kochanowskiego, Kielce. CzyżEwski Feliks, 1986, Atlas gwar polskich i ukrainskich okolic Włodawy, Wydawnictwo Uniwersytetu Marii Curie-Skłodowskiej, Lublin.

CzYŻEwSKI Feliks, 1988, O problemach interferencji językowej w ukraińskich gwarach wschodniej Lubelszczyzny, „Z Polskich Studiów Slawistycznych”, seria VII „Językoznawstwo”, s. 87-93.

CzyżEWSKr Feliks, 1994, Fonetyka i fonologia gwar polskich i ukraińskich potudniowo-wschodniego Podlasia, Wydawnictwo Uniwersytetu Marii Curie-Skłodowskiej, Lublin.

CzYżEwski Feliks, 2015, Kilka uwag o pograniczu językowym w świetle inskrypcji nagrobnych wschodniej Lubelszczyzny, w: F. Czyżewski, M. Olejnik, A. Pihan-Kijasowa, red., Pogranicza słowiańskie w opisach językoznawczych. W 110 rocznicę urodzin Profesora Władysława Kuraszkiewicza (1905-1997), Wydawnictwo Polihymnia, Lublin-Włodawa, s. 55-66.

DeJna Karol, 1990, Z zagadnień interferencji oraz integracji językowej w gwarach, „Rozprawy Komisji Językowej ŁTN”, t. XXXVI, s. 61-75.

Dejna Karol, 1991, Zzagadnień ewolucji oraz interferencji językowej, Wydawnictwo Łódzkiego Towarzystwa Naukowego, Łódź.

Dejna Karol, 1998, Gwara i jej stosunek do innych odmian języka ogólnonarodowego, w: S. Gala, red., Teoretyczne, dydaktyczne i badawcze założenia dialektologii, Wydawnictwo Łódzkiego Towarzystwa Naukowego, Łódź, s. 13-22.

Dunas Bogusław, 1980, Zagadnienia interferencji w badaniach dialektologicznych, „Biuletyn Polskiego Towarzystwa Językoznawczego”, t. XXXVII, s. $99-108$.

FalińsKa Barbara, KowalsKa Anna, 1983, Polsko-białoruskie i polsko-ukraińskie związi leksykalno-stowotwórcze, „Z Polskich Studiów Slawistycznych”, seria VI „Językoznawstwo”, s. 91-100.

Gala Sławomir, 1994, Małopolsko-śląsko-wielkopolskie pogranicze językowe, cz. I-II, Wydawnictwo Uniwersytetu Łódzkiego, Łódź. 
Gala Sławomir, 1997, Zmiany w gwarach Polski centralnej w XX wieku, w: E. Umińska-Tytoń, red., Interferencje w językach i dialektach stowiańskich, Wydawnictwo Łódzkiego Towarzystwa Naukowego, Łódź, s. 33-59.

Gala Sławomir, 2008, Kwestionariusz do badań stowotwórstwa i stownictwa w gwarach pogranicza wielkopolsko-małopolsko-mazowiecko-śląskiego, Wydawnictwo Uniwersytetu Łódzkiego, Łódź.

Gala Sławomir, Gala-Milczarek Beata, 2006, Jeszcze w sprawie metodyki badań pogranicza językowego, w: H. Pelcowa, red., Spotkania polsko-ukraińskie. Język - Kultura - Literatura, Wydawnictwo Państwowej Wyższej Szkoły Zawodowej, Chełm, s. 141-149.

Gala-MilczareK Beata, 2016, Czynnościowy charakter derywatów rzeczownikowych w gwarach pótnocnomałopolskich i przyleglych. Studium morfologiczno-leksykalne, Wydawnictwo Uniwersytetu Łódzkiego, Łódź.

JARos Irena, 2009, Nazwy środków czynności w gwarach łęczycko-sieradzkich. Studium stowotwórczo-leksykalne, Wydawnictwo Uniwersytetu Łódzkiego, Łódź.

JAROS Irena, 2011, Wpływ polszczyzny ogólnej na system słowotwórczy gwar (na przykładzie nazw środków czynności), „Rozprawy Komisji Językowej ŁTN”, t. LVII, s. 69-80.

JAROS Irena, 2016, Przymiotnikowe synonimy stowotwórcze w gwarach polskich (zarys problemu), w: J. Klimek-Grądzka, M. Nowak, red., Dawne z nowym taczac... In memoriam Mariani Kucała, Towarzystwo Naukowe Katolickiego Uniwersytetu Lubelskiego Jana Pawła II, Lublin, s. 23-37.

KĄŚ Józef, 1994, Interferencja leksykalna słownictwa gwarowego i ogólnopolskiego (na przykladzie gwar orawskich), Wydawnictwo Uniwersytetu Jagiellońskiego, Kraków.

KĄś Józef, 2001, Metodologia badań leksyki gwarowej w kontekście współczesnych przemian kulturowych i społecznych, w: J. Sierociuk, red., Gwary dziś. 1. Metodologia badań, Wydawnictwo Poznańskiego Towarzystwa Przyjaciół Nauk, Poznań, s. 191-200.

KąŚ Józef, KuREK Halina, 2001, Funkcjonowanie współczesnej polszczyzny. Język wsi, w: S. Gajda, red., Najnowsze dzieje języków słowiańskich. Język polski, Wydawnictwo Uniwersytetu Opolskiego, Opole, s. 440-459.

Kość Józef, 1999, Polszczyzna południowokresowa na polsko-ukraińskim pograniczu językowym w perspektywie historycznej, Wydawnictwo Uniwersytetu Marii Curie-Skłodowskiej, Lublin.

KraWcZYK-Tyrpa Anna, 2001, Tabu w dialektach polskich, Wydawnictwo Akademii Bydgoskiej, Bydgoszcz. 
KucAŁa Marian, 1960, O słownictwie ludzi wyzbywajacych sie gwary, „Biuletyn Polskiego Towarzystwa Językoznawczego", t. XIX, s. 141-156.

Kucharzyк Renata, 2012, O potrzebie socjolingwistycznego badania zmian w słownictwie gwarowym, w: H. Kurek, red., Języki słowiańskie w ujęciu socjolingwistycznym, Księgarnia Akademicka, Kraków, s. 67-76.

KucharzyK Renata, 2016, Leksyka gwarowa w komunikacji internetowej, w: H. Kurek, M. Święcicka, M. Peplińska, red., Bydgoskie Studia nad Pragmatyka Językowa, t. 2: Globalizacja a przemiany języków słowiańskich, Wydawnictwo Uniwersytetu Kazimierza Wielkiego, Bydgoszcz, s. 241-253.

KuRASZKIEWICZ Władysław, 1932, Djalektologja, przegląd gwar województwa lubelskiego, w: I. Czuma, red., Monografia statystyczno-gospodarcza województwa lubelskiego, t. I, Drukarnia Państwowa w Lublinie, Lublin, s. 273-324.

KuREK Halina, 1987, Przełaczanie kodu językowego, czyli socjologiczne aspekty wzajemnego oddziaływania języka literackiego i dialektów, „Język Polski”, R. LXVII, s. 63-69.

KuReK Halina, 1995, Przemiany językowe wsi regionu krośnieńskiego. Studium socjolingwistyczne, Wydawnictwo Universitas, Kraków.

KuReK Halina, 2003, Przemiany leksyki gwarowej na Podkarpaciu, Wydawnictwo Universitas, Kraków.

KUREK Halina, 2010, Przemiany kulturowo-językowego wizerunku polskiej wsi w ostatnim pótwieczu (na przykładzie gwar małopolskich), w: H. Kurek, A. Tyrpa, J. Wronicz, red., Studia Dialektologiczne IV, Prace Instytutu Języka Polskiego 134, Wydawnictwo Instytutu Języka Polskiego Polskiej Akademii Nauk, Kraków, s. 71-79.

KuREK Halina, 2018, Stownictwo gwarowe w epoce globalizacji, w: R. Przybylska, M. Rak, A. Kwaśnicka-Janowicz, red., Historia języka, dialektologia i onomastyka w nowych kontekstach interpretacyjnych, Wydawnictwo Uniwersytetu Jagiellońskiego, Kraków, s. 203-209.

ŁesIów Michał, 1978, Polsko-ukraińskie oboczności leksykalne w gwarach pogranicza, „Z Polskich Studiów Slawistycznych”, seria V „Językoznawstwo”, s. 279-286.

Marciniak-Firadza Renata, 2013, Nazwy osobowych wykonawców czynności $w$ gwarach małopolsko-mazowieckiego pogranicza językowego. Studium słowotwórczo-leksykalne, cz. 1, 2, Wydawnictwo Uniwersytetu Łódzkiego, Łódź.

MAzUr Jan, 1976-1978, Gwary okolic Bitgoraja, cz. 1: Fonologia, cz. 2: Fleksja, Zakład Narodowy im. Ossolińskich, Wrocław. 
Ożóg Kazimierz, 2001, Polszczyzna przełomu XX i XXI wieku. Wybrane zagadnienia, Wydawnictwo Otwarty rozdział, Rzeszów.

Pelcowa Halina, 1997, Stownictwo wschodniosłowiańskie w gwarach Polski środkowo-wschodniej w świetle związków językowych polsko-ukraińskich, w: F. Czyżewski, M. Łesiów, red., Ze studiów nad gwarami wschodniostowiańskimi w Polsce, „Rozprawy Slawistyczne”, t. 12, s. 189-211.

Pelcowa Halina, 2001a, Interferencje leksykalne w gwarach Lubelszczyzny, Wydawnictwo Uniwersytetu Marii Curie-Skłodowskiej, Lublin.

Pelcowa Halina, 2001b, Polsko-białorusko-ukraińskie paralele leksykalne $w$ świetle kulturowego dziedzictwa prasłowiańskiego, w: E. Smułkowa, A. Engelking, red., Język i kultura białoruska w kontakcie z sasiadami, Wydział Polonistyki Uniwersytetu Warszawskiego, Warszawa, s. 141-151.

Pelcowa Halina, 2001c, Kulturowa wartość słownictwa w gwarach pogranicza (na przykładzie gwar wschodniolubelskich), w: F. Czyżewski, red., Język i kultura na pograniczu polsko-ukraińsko-białoruskim, Wydawnictwo Uniwersytetu Marii Curie-Skłodowskiej, Lublin, s. 43-59.

Pelcowa Halina, 2009, Trwanie i przemijanie w języku i obyczajowości wiejskiej, w: J. Adamowski, J. Styk, red., Tradycja dla wspótczesności. Ciagłość i zmiana, t. 2: Tradycja w tekstach kultury, Wydawnictwo Uniwersytetu Marii Curie-Skłodowskiej, Lublin, s. 89-100.

Pelcowa Halina, 2012, Stownictwo kresowe jako element tożsamości pogranicza (na materiale gwar Lubelszczyzny), w: E. Dzięgiel, K. Czarnecka, D. Kowalska, red., Polskie dziedzictwo językowe na dawnych Kresach. Język polski dawnych Kresów Wschodnich, t. 5, Wydawnictwo Naukowe Semper, Warszawa, s. 257-264.

Pelcowa Halina, 2015a, Nazwa i desygnat w zmieniającej się rzeczywistości wiejskiej, w: U. Sokólska, red., Odkrywanie słowa-historia i wspótczesność, Wydawnictwo Uniwersytetu w Białymstoku, Białystok, s. 551-568.

Pelcowa Halina, 2015b, Dziedzictwo leksykalne pogranicza polsko-wschodniostowiańskiego winterpretacji mieszkańców wsi, w: F. Czyżewski, M. Olejnik, A. Pihan-Kijasowa, red., Pogranicza słowiańskie w opisach językoznawczych. W 110 rocznice urodzin Profesora Władystawa Kuraszkiewicza (1905-1997), Wydawnictwo Polihymnia, Lublin-Włodawa, s. 91-98.

Pelcowa Halina, 2016, Tendencje globalizacyjne w języku i kulturze a koncepcja „,małych ojczyzn”, w: H. Kurek, M. Święcicka, M. Peplińska, red., Bydgoskie Studia nad Pragmatyka Językowa, t. 2: Globalizacja a przemiany języków stowiańskich, Wydawnictwo Uniwersytetu Kazimierza Wielkiego, Bydgoszcz, s. 89-100. 
Pelcowa Halina, 2017, Tradycja lokalna i regionalna a globalizacja, „Poradnik Językowy" z. 10, s. 20-29.

Pinan-Kijasowa Alicja, 2015, Polszczyzna Kresów Wschodnich - efekt pogranicza językowego, w: F. Czyżewski, M. Olejnik, A. Pihan-Kijasowa, red., Pogranicza stowiańskie w opisach językoznawczych. W 110 rocznicę urodzin Profesora Władystawa Kuraszkiewicza (1905-1997), Wydawnictwo Polihymnia, Lublin-Włodawa, s. 97-104.

RAK Maciej, 2015, Kulturemy podhalańskie, Księgarnia Akademicka, Kraków.

ReIchan Jerzy, 1999, Gwary polskie w końcu XX w., w: W. Pisarek, red., Polszczyzna 2000. Orędzie o stanie języka na przełomie tysiacleci, Ośrodek Badań Prasoznawczych Uniwersytetu Jagiellońskiego, Kraków, s. 262-278.

RemBIsZEWSKa Dorota, 2002, Gwary nadbużańskie mazowiecko-podlaskie, Łomżyńskie Towarzystwo Naukowe, Łomża.

Rieger Janusz, 1983, Problemy interferencji językowej w ukraińskich gwarach karpackich w zakresie leksyki. Drogi przenikania zapożyczeń, „Z Polskich Studiów Slawistycznych”, seria VI „Językoznawstwo”, s. 303-312.

RiEger Janusz, 1997, Interferencje ukraińskie w gwarach polskich na Podolu, w: E. Umińska-Tytoń, red., Interferencje w językach i dialektach stowiańskich, Wydawnictwo Łódzkiego Towarzystwa Naukowego, Łódź, s. 134-140.

Rieger Janusz, 2015, Kilka słowackich paraleli do leksyki pótnocnołemkowskiej, w: F. Czyżewski, M. Olejnik, A. Pihan-Kijasowa, red., Pogranicza słowiańskie w opisach językoznawczych. W 110 rocznice urodzin Profesora Władystawa Kuraszkiewicza (1905-1997), Wydawnictwo Polihymnia, Lublin-Włodawa, s. $107-112$.

SIEROCIUK Jerzy, red., 2006, Gwary dziś. 3. Wewnętrzne zróżnicowanie języka wsi, Wydawnictwo Poznańskiego Towarzystwa Przyjaciół Nauk, Poznań.

Tyrpa Anna, 2019, Stare i nowe stowa w świadomości mieszkańców wsi, „Poradnik Językowy", z. 1, s. 20-32.

Walczak Bogdan, 2015, Pogranicze polsko-wschodniostowiańskie od średniowiecza do dziś, w: F. Czyżewski, M. Olejnik, A. Pihan-Kijasowa, red., Pogranicza stowiańskie w opisach językoznawczych. W 110 rocznice urodzin Profesora Władysława Kuraszkiewicza (1905-1997), Wydawnictwo Polihymnia, Lublin-Włodawa, s. 149-156.

WARCHOŁ Stefan, 1992, Specyfika gwar mieszanych i przejściowych na terenach etnicznie zróżnicowanych, „Rozprawy Slawistyczne 5”, Wydawnictwo Uniwersytetu Marii Curie-Skłodowskiej, Lublin. 


\title{
Halina Pelcowa \\ POGRANICZE JEZZYKOWE I KULTUROWE \\ POLSKO-WSCHODNIOSŁOWIAŃSKIE W OBLICZU TENDENCJI GLOBALIZACYJNYCH (NA MATERIALE GWAR LUBELSZCZYZNY)
}

\begin{abstract}
Streszczenie
Przedmiotem rozważań jest pogranicze językowe i kulturowe polsko-wschodniosłowiańskie rozpatrywane w aspekcie przeszłości i współczesności, z wyraźnie zarysowaną tożsamością regionalną, tendencjami globalizacyjnymi i aspektem świadomościowo-mentalnościowym mieszkańców wsi. Tak rozumiane pogranicze wpisuje się w globalizację i tożsamość lokalną z pojęciem małej ojczyzny oraz kultywowaniem tradycji regionu, sytuujących się w dwóch przeciwstawnych, a jednak wzajemnie spójnych przestrzeniach. Tworzą one nie tylko wąski obszar stykania się różnych odmian językowych i zjawisk kulturowych, ale i szeroki pas wzajemnych uwarunkowań współczesnych i historycznych, mających swoje odbicie w zachowaniach językowych najstarszych mieszkańców wsi, włączonych w nurt tendencji globalizacyjnych. Materiałem badawczym są wypowiedzi mieszkańców wsi regionu lubelskiego.
\end{abstract}

\section{THE LINGUISTIC AND CULTURAL POLISH-EAST SLAVIC BORDERLANDS IN THE CONTEXT OF GLOBALIZATION. A STUDY BASED ON DIALECT DATA OF THE LUBLIN REGION}

\section{Summary}

The study deals with the Polish-East Slavic past and present linguistic and cultural borderlands as seen through the prism of the globalizing and localist tendencies shown by the village population of the Lublin region with its clearly defined rural regional identity and self-awareness. Associated with the idea of the so-called 'little motherland' and with the cultivation of the regional tradition, regional identity and self-awareness spans two opposing but coherent cultural spaces in which the different language varieties and cultural strands of the past and present are met and reflected in the language of the oldest villagers confronted with present day globalizing tendencies. This study is based on data recorded in villages of the Lublin region. 